\title{
Fluorometric assay of oleate-activated phospholipase D isoenzyme in membranes of rat nervous tissue and human platelets
}

\author{
Marek Krzystanek ${ }^{\circledR}$, Henryk I. Trzeciak², Ewa Krzystanek³ and Andrzej Małecki ${ }^{4}$ \\ 1Department and Clinic of Psychiatry and Psychotherapy, Medical University of Silesia, Katowice, Poland; 2Department of Pharmacology, Medi- \\ cal University of Silesia, Sosnowiec, Poland; 3Department of Neurology, ${ }^{4}$ Department of Pharmacology, Medical University of Silesia, Katowice, \\ Poland
}

Phospholipase D plays a key role in the biosynthesis of phosphatidic acid, a second messenger involved in essential cellular processes. Oleate-activated phospholipase $D$ was the first mammalian phospholipase $D$ isoform to be discovered but is the least known. The study was aimed to test a fluorometric method of assessment of oleate-activated phospholipase D activity in different biological materials. The brain cortex of male Wistar rats, cultured rat brain astrocytes, and human platelets were processed to yield plasmatic membranes for experiments. To assess phospholipase D activity the modified fluorometric method was used. Previously, the method was used only to determine $\mathrm{H}_{2} \mathrm{O}_{2}$. In this enzyme-coupled assay phospholipase $\mathrm{D}$ activity is monitored indirectly using 10-acetyl-3,7-dihydroxyphenoxazine. First, phospholipase D cleaves exogenous phosphatidylcholine to yield choline and phosphatidic acid. Second, choline is oxidized by choline oxidase to betaine and $\mathrm{H}_{2} \mathrm{O}_{2}$. Final$l y$, in the presence of horseradish peroxidase, $\mathrm{H}_{2} \mathrm{O}_{2}$ reacts with 10-acetyl-3,7-dihydroxyphenoxazine to generate the highly fluorescent product, resorufin. The concentration of resorufin was measured using excitation and emission at $560 \mathrm{~nm}$ and $590 \mathrm{~nm}$, respectively. The proposed optimal parameters of the tested assay are $25 \mu \mathrm{g}$ of rat brain cortex protein, $50 \mu \mathrm{g}$ of rat brain astrocyte protein, and $50 \mu \mathrm{g}$ of human platelet protein in a reaction volume of $200 \mu \mathrm{L}$, and 2 min enzymatic reaction at $37^{\circ} \mathrm{C}$. The fluorometric method may be applied to assay phospholipase $\mathrm{D}$ in different biological materials.

Keywords: phospholipase D, membranes, fluorometric assay, rat brain, astrocytes, human platelets

Received: 06 May, 2010; revised: 24 June, 2010; accepted: 07 Septemeber, 2010; available on-line: 11 September, 2010

\section{INTRODUCTION}

Phospholipase D (EC 3.1.4.4., PLD) is a widespread enzyme present in most known mammalian cells, except in some leukocytes (Liscovitch et al., 1999). PLD activity was first described in 1947 in carrot cells (Hanahan \& Chaikoff, 1947). Until the early 1970s, PLD was thought to be present in plant cells only. However, Saito and Kanfer (1973) found oleate-dependent PLD activity in rat brain. The finding of the enzyme in animal tissue opened a new chapter in the understanding of the role of phospholipids in brain function. It is now known that PLD plays an important role in mitogenesis and cell differentiation, morphogenesis, synaptogenesis, intracellular transport and exocytosis, protein kinase activity regulation, neurodegeneration, and apoptosis (Klein, 2005). To date, PLD has been shown to participate in the pathogenesis of Alzheimer's disease, Parkinson's disease, alcoholism, brain ischemia, and brain ageing (Lotharius \& Brundin, 2002; Varga \& Alling, 2002; Krzystanek et al., 2006; Jin et al., 2007). The many functions performed by PLD in cellular physiology make oleate-activated PLD a candidate for a regulatory neuronal function.

Numerous PLD isoenzymes have been described, and in the future new isoforms will likely be characterized at various cell locations (Liscovitch et al., 1999). Those currently accepted include three human PLD isoforms (hPLD 1a, hPLD 1b, and hPLD 2) and four rat isoenzymes (rPLD 1a, rPLD 1b, rPLD 2, and the oleate-activated PLD discovered by Saito and Kanfer) (Liscovitch et al., 1999; Saito \& Kanfer, 1973).

Oleate-activated PLD is an integral membrane protein (Liscovitch et al., 1999). Its activity has been described in rat brain plasmatic membranes, synaptic membranes, microsomes, and neuronal nuclei (Liscovitch et al., 1999). The enzyme acts specifically on phosphatidylcholine (PC), a major structural component of the cell membrane (Horwitz \& Davis, 1993). The products of PC hydrolysis are phosphatidic acid (PA) and choline. PA is thought to be a key element of a PLD-dependent intracellular messenger system (English et al., 1996). However, the exact role played by oleate-activated PLD in cells is still poorly understood and requires further research.

In 1990, Chalifa and coworkers described a radiometric assay for oleate-activated PLD in rat brain plasmatic membranes. This method provided a reliable tool for experiments on the role of the enzyme in intracellular processes in the brain, but it is somewhat cumbersome. The purpose of the present paper is to present the results of our efforts to find a useful way of assessment of oleate-activated PLD in different biological materials: rat brain cortex, rat astrocytes, and human platelets. We reasoned that a fluorometric assay would be more convenient than a radiometric one. We therefore used a modification of Zhou and coworkers method for the fluorometric determination of $\mathrm{H}_{2} \mathrm{O}_{2}$ (Zhou et al., 1997), employing 10-acetyl-3,7-dihydroxyphenoxazine in an enzyme-coupled assay to indirectly monitor the activity of oleate-activated PLD in plasmatic membranes of rat

e-mail: krzystanekmarek@gmail.com

Abbreviations: HP, human platelets; PA, phosphatidic acid; PC, phosphatidylcholine; PLD, phospholipase D; RBA, rat brain astrocytes; RBC, rat brain cortex 


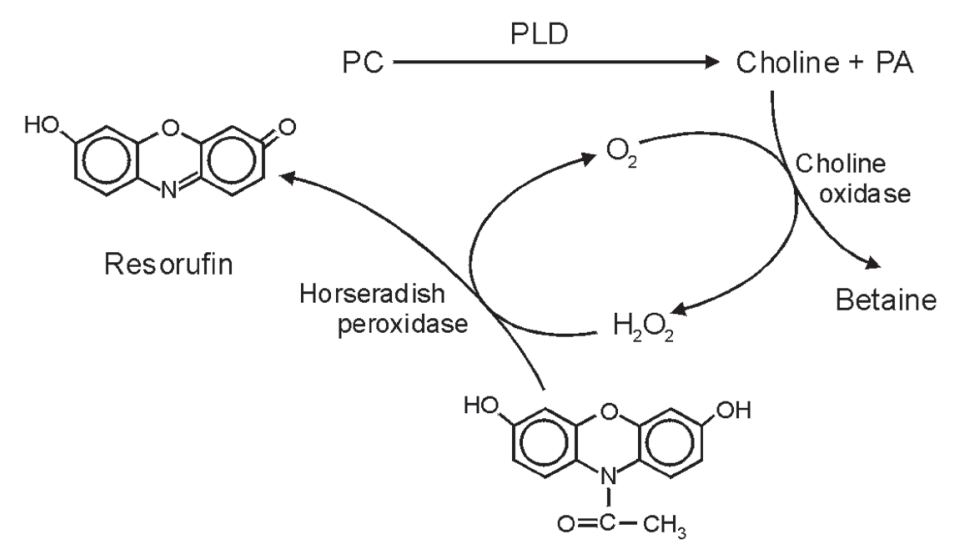

10-acetyl-3,7-dihydroxy phenoxazine

Figure 1. Principle of fluorometric assay of phospholipase D (PLD) activity. Used with permission of Molecular Probes (The Netherlands). PC, phosphatidylcholine; PA, phosphatidic acid.

brain cortex, cultured rat brain astrocytes, and human platelets.

The principle of the assay is shown in Fig. 1. To characterize this modified fluorometric method, we tested it under various conditions of PLD measurement similar to those described by Chalifa et al. (1990).

\section{MATERIALS AND METHODS}

Materials. Bovine serum albumin was obtained from Genzyme (Neu-Isenburg, Germany). Ethylenediaminetetraacetic acid disodium salt (EDTA disodium salt) and resorufin were from Sigma (St. Louis, MO, USA). TRIZMA base was from Serva (Heidelberg, Germany). Oleic acid (sodium salt) was from Sigma-Aldrich (Seelze, Germany). The following reagents were from the Amplex Red Phospholipase D Assay Kit, A-12219 (Molecular Probes (Invitrogen, Leiden, The Netherlands): dimethylsulfoxide (DMSO, anhydrous), L-alpha-PC (lecithin), 10-acetyl-3,7-dihydroxyphenoxazine, horseradish peroxidase (HRP), and choline oxidase from Alcaligenes sp. All other reagents were of analytical grade and were purchased from POCh S.A. (Gliwice, Poland).

Isolation of rat brain cortex (RBC) plasmatic membranes. Male Wistar rats weighing $220 \pm 10 \mathrm{~g}$ were used to obtain brain plasmatic membranes. The experimental group consisted of eight rats. Plasmatic membranes of the rat brains were isolated according to the method described by Jelsema (1987) and modified by Strosznajder and Strosznajder (1989). Briefly, after decapitation, the brain was rapidly removed and put on ice. Dissected brain cortex was homogenized in an icecold Potter-Elvenhjem homogenizer in a medium containing $0.32 \mathrm{M}$ sucrose, $10 \mathrm{mM}$ Tris/ $\mathrm{HCl}$ buffer $(\mathrm{pH}$ $7.4)$, and $1 \mathrm{mM}$ EDTA. The homogenate $(10 \%, \mathrm{w} / \mathrm{v})$ was centrifuged for $3 \mathrm{~min}$ at $1100 \times g$. The supernatant was centrifuged for $10 \mathrm{~min}$ at $17000 \times \mathrm{g}$ to obtain a $\mathrm{P}_{2}$ fraction. Subsequently, the $\mathrm{P}_{2}$ fraction was dispersed in $1 \mathrm{mM}$ Tris/HCl buffer ( $\mathrm{pH}^{2}$ 7.4) for hypotonic shock, then vortexed and centrifuged for $20 \mathrm{~min}$ at $48000 \times \mathrm{g}$. The resulting pellet contained brain plasmatic membranes. The pellet was gently resuspended in the modified buffer used by Chalifa et al. (1990) (50 mM Tris/ $\mathrm{HCl}, 1 \mathrm{mM} \mathrm{MgCl}, 1 \mathrm{mM}$ EDTA, $\mathrm{pH}$ 7.2) and imme- diately frozen at $-70{ }^{\circ} \mathrm{C}$ for further experiments.

Isolation of rat brain astrocytes (RBA) plasmatic membranes. Cultured RBA were obtained using the method of Hertz et al. (1985). RBA normoxemic cultures were used. Astrocytes from 10 cultures were sonicated 3 times for $10 \mathrm{~s}$ at energy lower than $3 \mathrm{~W}$, after sonication the homogenate was vortexed for $10 \mathrm{~s}$ and used to examine membrane PLD activity.

Isolation of human platelets (HP) plasmatic membranes. Human cells were isolated according to modified methods of David and Herion (1972) and Girotti et al. (1991). Platelets were collected from 20 healthy subjects and stored at $-70^{\circ} \mathrm{C}$. The platelets were unfrozen, vortexed for $10 \mathrm{~s}$ and sonicated as described for RBA. Later on the material was vortexed for $10 \mathrm{~s}$ and used to assess PLD activity in HP membranes.

Protein determination. Protein was determined in the plasmatic membrane samples, using the method described by Lowry et al. (1951).

Determination of PLD activity in RBC, RBA and HP. The fluorometric assays were carried out in a Fluoroscan Ascent FL device type 374 (Labsystems, Helsinki, Finland). The filters were set for excitation at $560 \mathrm{~nm}$ and emission at $590 \mathrm{~nm}$. The standard reaction mixture contained $50 \mathrm{mM}$ Tris/ $\mathrm{HCl}(\mathrm{pH} 7.2), 1 \mathrm{mM}$ $\mathrm{MgCl}_{2}, 1 \mathrm{mM}$ EGTA, $100 \mu \mathrm{M}$ 10-acetyl-3,7-dihydroxyphenoxazine, $2 \mathrm{U} / \mathrm{mL}$ HRP, $0.2 \mathrm{U} / \mathrm{mL}$ choline oxidase, $0.5 \mathrm{mM}$ lecithin and $4 \mathrm{mM}$ sodium oleate (Chalifa et al., 1990). The final reaction volume was $200 \mu \mathrm{L}$ per assay. Assays were performed using 96-well microplates (Black Cliniplate, Labsystems, Breda, The Netherlands) at $37^{\circ} \mathrm{C}$ with jet sample addition of initiating reagents.

To optimize the time of reaction and amount of plasmatic membrane protein in the reaction mix, the PLD assessments were performed after every minute for $10 \mathrm{~min}$ and after $15 \mathrm{~min}$ with different amounts of protein (between $10 \mu \mathrm{g}$ and $60 \mu \mathrm{g}$ ) in the reaction volume. An accumulation curve of resorufin was also calculated. The reaction was carried out under different conditions, i.e., varying $\mathrm{pH}$ and concentration of sodium oleate in the reaction mixture.

Preparation of resorufin calibration curve. To calculate PLD activity, Ascent FL Fluoroscan software was used to construct a calibration curve with arbitrary units of fluorescence plotted against resorufin concentration. The calibration curve was linear in the range used in these experiments ( 0 to 20 arbitrary units of fluorescence).

\section{RESULTS}

To assess the optimal concentration of the surfaceactive agent sodium oleate in the reaction tested, we incubated RBC, RBA and $\mathrm{HP}$ membranes (at $37^{\circ} \mathrm{C}, \mathrm{pH}=$ 7.2) at different sodium oleate concentrations. The highest activity of the enzyme was obtained at $4 \mathrm{mM}$ sodium oleate. When the incubation was carried out without sodium oleate, no production of resorufin was detected.

We also varied the amount of RBC, RBA and HP membrane protein in the reaction mixture. The assessments were performed at $37^{\circ} \mathrm{C}$ and $\mathrm{pH} 7.2$ in the presence of $4 \mathrm{mM}$ sodium oleate. The kinetics of the reac- 
tion was slowed down at concentration higher than 25 $\mu \mathrm{g}$ RBC protein, $50 \mu \mathrm{g}$ RBA protein and $50 \mu \mathrm{g} \mathrm{HP}$ protein in the reaction well. At all concentrations, the dynamics of the reaction reached a peak within the first $2 \mathrm{~min}$ and then the reaction slowed down. We assumed $2 \mathrm{~min}$ as the optimal time to measure PLD activity in the biological materials examined.

To characterize the influence of different amounts of the plasmatic membrane protein on accumulation of PLD products, we calculated four accumulation curves. From the second through tenth minute of the experiment, the accumulation of resorufin was near linear at all the protein concentrations tested.

It was confirmed that the PLD activity measured is dependent on lecithin concentration; with concentrations of lecithin exceeding $0.5 \mathrm{mM}$, the enzyme became saturated. The hydrolysis of lecithin by PLD satisfied Michaelis-Menten kinetics.

To determine whether $\mathrm{pH}$ has an impact on PLD activity, assays at different $\mathrm{pH}(6.8,7.2$ and 7.6) were performed. The optimal $\mathrm{pH}$ for RBC, RBA and HP plasmatic membrane enzyme was 7.2.

PLD activity measured under optimal experimental conditions was $10.05 \pm 2.2 \mathrm{nmol} / \mathrm{mg}$ per min in $\mathrm{RBC}$ plasmatic membranes, $0.26 \pm 0.07$ in RBA membranes and $1.62 \pm 0.49$ in HP plasmatic membranes.

\section{DISCUSSION}

The PLD described by Saito and Kanfer in 1973 is referred to as the oleate-activated isoform (Chalifa et al., 1990; Liscovitch et al., 1999). Despite many years of studies, the amino-acid sequence, regulation, and function of oleate-activated PLD have remained unknown (Liscovitch et al., 1999). However, because of the broad range of functions played by $\mathrm{PA}$, which is produced by PLD in the membrane, oleate-dependent PLD may have an important role in proper neuronal function as well as in nervous system disorders. Indirect data suggest that PLD activity levels may influence the pathomechanisms of alcoholism (Varga \& Alling, 2002), brain ischemia (Nishida et al., 1994), Parkinson's disease (Lotharius \& Brundin, 2002) and brain ageing (Venable \& Obeid, 1999). Our own experimental data indicate that oleateactivated PLD may affect the mechanism of action of some psychotropic drugs (unpublished).

The PLD isoenzyme examined in our experiments is oleate-dependent and that makes it easy to distinguish from other isoforms of PLD. It has been previously shown that cloned $\mathrm{PLD}_{1}$ and $\mathrm{PLD}_{2}$ do not have transmembrane domains, and their activation depends on the presence of phosphatidylinositol-4,5-bisphosphate $\left(\mathrm{PIP}_{2}\right)$ (Houle \& Bourgoin, 1999). Oleate-activated PLD is an integral membrane protein and its activity is preserved after the isolation of brain plasmatic membranes. Both $\mathrm{PLD}_{1}$ and $\mathrm{PLD}_{2}$ are inhibited by sodium oleate (Meier et al., 1999). Because of the specificity of oleate-activated PLD towards lecithin, exogenous lecithin was used as a substrate in our experiments (Horwitz \& Davis, 1993).

To confirm that the enzyme assessed in our experiments is indeed the oleate-dependent PLD described by Chalifa et al. (1990), we examined its activity under similar conditions. The enzyme that we assessed fluorometrically is indeed oleate-dependent. Previous studies have also found that activation of membrane-bound mammalian PLD requires sodium oleate (Taki \& Kanfer, 1979).
A pH of 7.2 is assumed to be physiological for plasmatic membranes. Chalifa et al. (1990) found the optimal $\mathrm{pH}$ for oleate-activated PLD in rat brain membranes to be near neutral. The peak PLD activities at $\mathrm{pH} 7.2$ determined in our experimental model agree with those findings.

The optimal parameters in our assay were: $25 \mu \mathrm{g}$ of the RBC, $50 \mu \mathrm{g}$ of the RBA and $50 \mu \mathrm{g}$ of the HP protein in a reaction volume of $200 \mu \mathrm{L}, \mathrm{pH}=7.2$, and 2 min of the enzymatic reaction. Lecithin at $0.5 \mathrm{mM}$ was in excess in the reaction mixture.

The use of the fluorometric approach in the assessment of phospholipase D provides a convenient method that is easy to apply in the laboratory. Our studies indicate that the method can also be used in other biological materials from human and rat (Krzystanek et al., 2002; $2003 ; 2004 ; 2006 ; 2007)$. The fluorometric method is not time consuming, and the results are comparable to those obtained using the radiometric method. Furthermore, the method is inexpensive. The use of this method to assay oleate-activated PLD in rat brain may contribute to further elucidation of the role the enzyme plays in various cells.

\section{REFERENCES}

Chalifa V, Mohn H, Liscovitch M (1990) A neutral phospholipase D activity from rat brain synaptic plasma membranes. J Biol Chem 265: 17512-17519.

David JL, Herion F (1972) Assay of platelet ATP and ADP by the luciferase method: some theoretical and practical aspects. Adv Exp Med Biol 34: 341-354.

English D, Cui Y, Siddiqui RA (1996) Messenger functions of phosphatidic acid. Chem Phys Lipids 80: 117-132

Girotti S, Ferri E, Cascione ML, Orlandini A, Farina L, Nucci S, Di Graci F, Budini R (1991) Methodological problems of direct bioluminescent ADP assay in platelets and erythrocytes. Anal Biochem 192: $350-357$.

Hanahan DJ, Chaikoff IL (1947) A new phospholipid-spliting enzyme specific for the ester linkage between the nitrogenous base and the phosphoric acid grouping. J Biol Chem 169: 699-705.

Hertz L, Juurlink BHJ, Szuchet S (1985) Cell Cultures. In Handbook of Neurochemistry. Lajtha A ed, 8: 603-661. Plenum Press, New York, London.

Horwitz J, Davis LL (1993) The substrate specificity of brain microsomal phospholipase D. Biochem J 295: 793-798.

Houle MG, Bourgoin S (1999) Regulation of phospholipase D by phosphorylation dependent mechanism. Biochim Biophys Acta 1439: 135-150.

Jelsema CL (1987) Light activation of phospholipase A2 in rod outer segments of bovine retina and its modulation by GTP-binding proteins. J Biol Chem 262: 163-168.

Jin JK, Ahn BH, Na YJ, Kim JI, Kim YS, Choi EK, Ko YG, Chung KC, Kozlowski PB, Min do S (2007) Phospholipase D1 is associated with amyloid precursor protein in Alzheimer's disease. Neurobiol Aging 28: 1015-1027.

Klein J (2005) Functions and pathophysiological roles of phospholipase $\mathrm{D}$ in the brain. J Neurochem 94: 1473-1487.

Krzystanek M, Trzeciak HI, Krupka-Matuszczyk I, Krzystanek E (2002) Antidepressant-like influence of olanzapine on membrane phospholipase D activity in rat brain. Eur Neuropsychopharmacol 12 (Suppl 3): S297.

Krzystanek M, Krupka-Matuszczyk I, Trzeciak IH, Krzystanek E (2003) Amitriptiline mechanism of action may relate to oleate activated phospholipase D inhibition. Eur Neuropsychopharmacol 13 (Suppl 4): S235.

Krzystanek M, Krupka-Matuszczyk I, Trzeciak HI, Krzystanek E (2004) Classical neuroleptics do not change the membrane phospholipase D activity. Eur Neuropsychopharmacol 14 (Suppl 3): S239S240.

Krzystanek M, Krupka-Matuszczyk I, Trzeciak HI, Krzystanek E (2006) Phospholipase D activation as a possible apoptotic signal in ischemic astrocytes. Eur Neuropsychopharmacol 16 (Suppl 4): S486S487.

Krzystanek E, Krzystanek M, Opala G, Trzeciak HI, Siuda J, Małecki A (2007) Platelet phospholipase A2 activity in patients with Alzheimer's disease, vascular dementia and ischemic stroke. I Neural Transm 114: 1033-1039. 
Liscovitch M, Czarny M, Fiucci G, Lavie Y, Tang X (1999) Localization and possible functions of phospholipase D isozymes. Biochim Biopbys Acta 1439: 245-263.

Lotharius J, Brundin P (2002) Impaired dopamine storage resulting from alpha-synuclein mutations may contribute to the pathogenesis of Parkinson's disease. Hum Mol Genet 11: 2395-2407.

Lowry OH, Rosebrough NJ, Farr AL, Randall RJ (1951) Protein measurement with the Folin phenol reagent. I Biol Chem 193: 265-275.

Meier KE, Gibbs TC, Knoepp SM, Ella KM (1999) Expression of phospholipase D isoforms in mammalian cells. Biochim Biophys Acta 1439: 199-213.

Nishida A, Emoto K, Shimizu M, Uozumi T, Yamawaki S (1994) Brain ischemia decreases phosphatidylcholine-phospholipase $\mathrm{D}$ but not phosphatidylinositol-phospholipase C in rats. Stroke 25: 1247-1251.

Saito M, Kanfer J (1973) Solubilization and properties of a membranebound enzyme from rat brain catalyzing a base-exchange reaction. Biochem Biophys Res Commun 53: 391-398.
Strosznajder J, Strosznajder RP (1989) Guanine nucleotides and fluoride enhance carbachol-mediated arachidonic acid release from phosphatidylinositol. Evidence for involvement of GTP-binding protein on phospholipase $A_{2}$ activation. J Lipid Mediat 1: 217-229.

Taki T, Kanfer JN (1979) Partial purification and properties of a rat brain phospholipase D. J Biol Chem 254: 9761-9765.

Varga A, Alling C (2002) Formation of phosphatidylethanol in vitro in red blood cells from healthy volunteers and chronic alcoholics. $J$ Lab Clin Med 140: 79-83.

Venable ME, Obeid LM (1999) Phospholipase D in cellular senescence. Biochim Biophys Acta 1439: 291-298.

Zhou M, Diwu Z, Panchuk-Voloshina N, Haugland RP (1997) A stable nonfluorescent derivative of resorufin for the fluorometric determination of trace hydrogen peroxide: applications in detecting the activity of phagocyte NADPH oxidase and other oxidases. Anal Biochem 253: 162-168. 